INTERNATIONAL JOURNAL OF MULTidisciplinARY RESEARCH AND ANALYSis

ISSN(print): 2643-9840, ISSN(online): 2643-9875

Volume 05 Issue 02 February 2022

DOI: 10.47191/ijmra/v5-i2-27, Impact Factor: 6.072

Page No. 420-435

\title{
Character Formation through Internalization of Religious Values in Elementary School Students
}

\author{
Iswan' ${ }^{1}$, Ma'mun Murod $^{2}$, Herwina Bahar ${ }^{3}$, Imam Mujtaba ${ }^{4}$ \\ 1,2,3,4 Universitas Muhammadiyah Jakarta, South Jakarta. Indonesia
}

\begin{abstract}
This research was conducted in elementary school Lab. School FIP-UMJ, South Tangerang. Indonesia. The research method used is a qualitative descriptive approach. The number of respondent studies was 25 students who actively participated in extracurricular activities through the internalization of the habit of reading the Koran. The results showed that the student's character was very good after they mastered the reading of the Koran well, had good attitudes and character. The attitude of the students that is formed is that they are aware to carry out worship because it is God's command. Spontaneous activities are in the form of giving warnings to students who make mistakes by advising and asking children to apologize. Therefore, as an effort to find a standard and ideal strategy in internalizing religious values in character building so that all attitudes a behavior of students are in accordance with the values of religious character, and thirdly, environmental based, student activities where students have a grand Taksmi program, activities that involving parents and guardians. The family is the first and foremost place for children's growth and development. The basis of character education should be applied from childhood or what psychologists call the golden age, because this age has been proven to greatly determine a child's ability to develop his potential. About $50 \%$ of the variability of adult intelligence occurs when the child is 4 year. The next $30 \%$ increase occurs at the age of 8 years, and the remaining $20 \%$ in the middle or late second decade. From here, character education should start from within the family which is the first environment for the growth of children's character.
\end{abstract}

KEYWORDS: character formation, internalization of religious values, elementary school.

\section{INTRODUCTION}

Education is a means to create intelligent human beings as well as to form human beings with character. Education does not only form intelligent human beings in terms of intellectual. However, the formation of character is also a very important part. Because, if education is only concerned with the creation of highly intellectual human beings without prioritizing good character, it will certainly lead to a bad nation. According to Mastuhu (2007), in Jamal Ma'mur Asmani (2011: 49), globalization provides extraordinary opportunities and facilities for anyone who is willing and able to take advantage of it, both for their own ben efit and for the benefit of the whole human being. The keyword of globalization is competition. The competition, which comes out as the winner is the best in terms of knowledge, technology, network, product quality, service, integrity, and accountability, Indonesia, in the context of knowledge and technology, is still far below developed countries. Indonesia is still a nation of consumers who like to enjoy globalization's products.

Globalization has penetrated all corners of the world, even to remote areas, entering homes, bombarding moral and religious defenses, no matter how strong they are defended. Television, internet, newspaper, cellphones, and others are information and communication med that run quickly, rolling up traditional barriers that have been held firmly. In Indonesia, there are still many students who are involved in immoral behavior, fighting, drugs, sexual harassment, murder, and drinking. Cases of minors who are pregnant out of wedlock also add to the evidence of the number of failed products from existing education. According to Muslich (2007:67), that the decline of this nation is nothing but because in essence we are experiencing a character crisis.

This character development has been forgotten by the school so far. Schools are too focused on targeting national exams and other academic competencies. Intellectual intelligence is cultivated, while emotional and spiritual intelligence is marginalized. As a result, intellectual intelligence is destroyed because of the fragility of emotional and spiritual intelligence. Therefore, the government in an effort to improve the character of the nation's children is intensively implementing character 


\section{Character Formation through Internalization of Religious Values in Elementary School Students}

education in the school environment. As stated by Muhaimin (2013:15), that currently, education in Indonesia is considered by many to be not problematic with the role of education in educating its students, but is considered less successful in building the personality of its students to have noble character. Therefore, character is seen as an urgent need.

Character education is one of the government's efforts in realizing national education goals. In accordance with the contents of Article 3 of Law Number 20 of 2003 concerning the National Education System which states that national education functions to develop capabilities and shape the character and civilization of a dignified nation in the context of educating life, aiming to develop the potential of students to become human beings who believe and put their trust, to God Almighty, noble, healthy, knowledgeable, capable, creative, independent and become a democratic and responsible citizen. However, in some elementary schools there is still no serious effort and consistency of teachers in instilling religious values in the formation of student character so that all student attitudes and behavior are in accordance with religious character, so in this study the researchers found that.

SD Lab. School FIP-UMJ is one of the elementary school that implements the internalization of religious values in the formation of the character of its students. SD Lab School FIP-UMJ is one of pilot Project School for the Ministry of Education and Culture's character education strengthening program. The internalization of religious values in the formation of student's character is clearly written in the vision and mission of SD Lab. School FIP-UMJ. The vision of SD Lab. Scholl FIP-UMJ is the realization of a leading and modern school with environmental insight in creating a generation of noble character in 2020 . Its missions are (1) to form a complete Indonesian human being, namely a man who is faithful and devoted, (2) to create a disciplined person, innovative, creative, have high solidarity and are future oriented, (3) develop student's abilities to have religious, national and state awareness, (4) develop children's potential according to their interest and talents, (5) build children's intelligence through multiple intelligences, (6) developing a culture of discipline and a high work ethic, (7) raising the spirit of achievement of all school members, (8) raising children awareness of caring for the environment, living clean and healthy, and (9) involving students in environmental action activities. Religious character is the foundation in the formation of children character, if the religious character is good then the other characters are also good.

Seeing the importance of character education, especially religious values in forming the character of students, it must be carried out and applied to students as early as possible so that I becomes a solid foundation for students so that in the future they are not easily carried away by the negative impacts of globalization and the negative impacts of lifestyle trends. Therefore, as and effort to find a standard and ideal strategy in internalizing religious values in character building so that all attitudes and behavior of students are in accordance with religious character values, in this study the researchers found that SD Lab. School FIP-UMJ is an elementary school that implements the internalization of values, religious values in the formation of the character of the students.

Based on the results of observations made by researchers in class 4.1 of SD Lab. School FIP-UMJ, South Tangerang. Indonesia, the efforts made by teachers in internalizing religious, values in the formation of the character of student are through prayer activities before and after learning activities as well as saying the meaning of the prayer, Qiroahti every morning before learning activities, performing the Dhuha prayer in congregation, Zuhur prayer in congregation every day, Infaq every time Friday, always getting used to lining up and reading prayers in and out of the bathroom, and there are extracurricular activities in which there is a process of character building, shaking hands with greetings before entering class and class entry day starting with the right foot.

\section{Formulation of the Problem}

1. How to apply the internalization of religious values to elementary school students from Lab School FIP-UMJ, South Tangerang. Indonesia?

2. How to integrate religious values in the character formation of elementary school students from Lab School FIP-UMJ, South Tangerang, Indonesia?

3. What is the role of extracurricular activities in schools in shaping the character of elementary school students at Lab School FIP-UMJ, South Tangerang, Indonesia?

\section{Research Purposes}

1. To find out how to implement the internalization of religious, values in character education in the elementary school Lab School FIP-UMJ, South Tangerang, Indonesia.

2. To find out how to integrate religious values in character building of elementary school student in the Lab School FIP-UMJ, South Tangerang, Indonesia.

3. To find out and analyze the role of extracurricular and character building of Lab School FIP-UMJ, South Tangerang, Indonesia. 


\section{Character Formation through Internalization of Religious Values in Elementary School Students}

\section{THEORETICAL REVIEW}

Internalization and values, according to the Big Indonesian Dictionary (KBBI) (2005:439) internalization according to nouns is defined as appreciation: the state's philosophical processes take place in depth through counseling, upgrading, and so on, doctrine or value so that it is a belief and awareness and the truth of a doctrine or value that is embodied in attitudes and behavior. According to Mustari (2014:5), he argues that internalizing means "to internalize" or "to house oneself" or "to internalize" or to place in "ownership" or "to make full members". This internalization process takes place at the same as the adoption and dissemination of values obtained from religious instructions.

Based on the description above, it can be concluded that internalization is a process of entering values or incorporating ideal attitudes that were previously considered to be outside, so that they are incorporated into one's thinking in one's thoughts, skills, and attitudes to life. Internalization is an effort to share knowledge (knowledge sharing). Internalization thus, can also be translated as one of the methods, procedures, and techniques in the knowledge management cycle used by educators to provide opportunities for members of a group, organization, agency, company, or student to share their knowledge with other members, or someone else.

\section{Internalization Process}

The process of internalization is a process that takes place throughout an individual's life, from the moment the individual is born until the end of his life. Throughout his life an individual continues to learn to cultivate all the feelings, desires, passions, and emotions that make up his personality. The first feelings that are activated in the personality when a baby is born are satisfaction and dissatisfaction, which causes him to cry. Humans have a talent that has been contained in the genes to develop various kinds of feelings, desires, passions, and emotion in their individual personality. But its form and activation is strongly influenced by various kinds of stimulation in the natural surroundings, social and cultural environment.

The internalization process is basically only obtained from the family, but also from the environment. The environment in question is the social environment. Unconsciously we have been influenced by various community leaders, such as Kyai, Ustad, teachers, and others. We can learn some things that we get from them which then make it a personality and culture. Internalization is a process of inculcating cultural values. The cultivation and growth of these values is carried out though various didactic-methods of education and teaching, such as education, guidance between indoctrination brainwashing, and so on.

According to Mustari (2014:1), religious is the value of character in relation to God. This shows that a person's thoughts, words, and actions are always based on divine values or religious teachings. Religious character values are all values related to religious teachings. Indonesia is a religious nation. This is stated in the view of life of the Indonesian people, namely Pancasila. The first precept of Pancasila is belief in One Supreme God. It is clear that the value of divinity is the first value and becomes the foundation in the life of the nation and state. The most important religious character inculcation is carried out in the new family environment, then continues in the school and community environment. According to Asmani (2011:50), states that education must begin to be built at home (home) and developed in school educational institutions (schools), even implemented in real life (community), and even includes the business world and industrial world (business).

Meanwhile, according to Hariyanto (2013:110), states that education expert in Indonesia generally agree that character education should start from the age of children (golden age), because this age is proven to greatly determine a child's ability to develop his potential. Golden age is in the age range of 4-6 years. Although the internalization of religious character is very important to be implanted in the age range of 4-6 years, the continuation of the process of internalizing religious values in character building is very necessary to be carried out at the age of 7-12 years, namely the age of elementary school children. Seeing the importance of internalizing religious values in character building in students as early as possible, a standard strategy is needed in order to internalize religious values in the formation of student character.

\section{Understanding Religious Values}

In the Big Indonesian Dictionary (2002:783), value means price, intelligence, a lot of content or something that perfects humans according to their essence. Through values, humans can perceive their past experiences, live their present lives and answer future challenges for the task of perfecting themselves as beings who live together with other people in the world. As an appreciation of values, humans are able to weigh and assess their past journeys. What is in the past becomes a long chain for the creation of meaning for his life from the historical chain for generations to come.

According to Kurniawan (2013:38), states that the values developed in character education in Indonesia are identified as coming from one source (in this case religion, Pancasila, culture, and the goals of National Education) the first, namely religion. Indonesia society is a religious society. In every aspect of individual life, society and nation are always based on religious teachings and beliefs. It should be underlined that the values of character education must be based on values derived from religion. Because if the religious values are good, then the other values will also be good. 


\section{Character Formation through Internalization of Religious Values in Elementary School Students}

Religious character must be instilled in students from an early age. The process of forming religious character, students will not take place by themselves, but the process is influenced by the school environment. All events that occur in schools should be integrated into character education programs, character education is a joint effort of all school members to create a new culture in schools, namely the culture of character education. The application of religious character education is now absolutely necessary not only at school, but at home and in the social environment. Even today, not only early childhood to adolescence, but also in adulthood, religious character education is absolutely necessary for the survival of this nation. Because Islamic religious character is an inherent characteristic of a person or object that shows Islamic identity, characteristics, obedience or impression.

Internalization of religious values is a process or method of instilling normative values that determine the desired behavior for a system that educated in accordance with the demands towards the formation of a national personality with character, which is based on religious values in accordance with the religion it adheres to. Religious character is related to religious teachings related to divinity or spirituality. So someone who has internalized religious values in himself, then all thoughts, words, and actions are based on the teachings he adheres to.

\section{Definition of Character Education}

Understanding education, etymologically, the word education comes from the basic word students, which get prefixes and suffixes. Turns into a verb to educate, which means helping children to master various knowledge, skills, attitudes, and values inherited from their family and society. This term first appeared in Greek, namely pedagogic which means association with children. The person who guides or educates children is a pedagogue. The word educare in Latin has the connotation of training or taming (as in the context of humans fruitful because the land is tilled and cultivated). So, education is process that helps grow, develop, mature, make the unorganized or wild become more organized, a kind of process of creating a culture and order in oneself and in others. A part from being a kind of domestication process, education also means the process of developing various kinds of potentials that exist in humans, such as academic, relational, talents, talents, physical abilities, or artistic abilities.

According to Albertus (2010:45), the word educare is a combination of the preposition ex (which means to get out of), and the verb educare (to lead). Therefore, educare can mean an activity to draw out or bring out. Education can mean a mentoring process in which there are two vertical relationship, between those who lead (dux) and those who are led. The relationship between the two is directed at one particular goal. Looking at the preposition ex used, this outward guidance process can mean internally or externally. Internally is the ability of humans to get out of their natural physical limitations. Humans, through the educational process, are able to work together with others outside of themselves to achieve the common goal of a society that helps each individual grow in the process of self improvement. He is able to cooperate and devote himself to a life whose interests reach the interests of many.

The word educare at first refers more to organic aspects, such as taming, guarding, mentoring, nurturing, nutrition, health, while the word educare refers more to more interior aspects, such as imagination, observation, intelligence, reason, way of thinking, attitude, critical, emotional, expressive, and operational. Historically, the word education has been widely used to refer to various meanings, such as development, growth/development, formation, socialization, in culture, teaching, training, renewal. The word education also involves interaction with various kinds of special institutional environments, such as family, schools, places of worship, groups, associations, foundations, movements. But at the same time it demands social responsibility within the framework of its relation complexity.

According to Made Pidarta (2004:30), there are several words that refer to educational activities. The word education, for example, is closer to the element of teaching (instruction) which has a very scholastic nature. Meanwhile, for the words growth and care, the term used is Bring-in up (this is closer to the meaning of maintenance and care in a family context). While the word training refers more to training, that is, a process that makes a person have the abilities to act (skills). Elements of teaching, care, and training, are part of an educational process itself.

In terms, education can be interpreted as a conscious and planned effort to create a learning atmosphere and learning process so that students actively develop their potential to have religious spiritual strength, self control, personality, intelligence, noble character, and skills needed by themselves, society, and society, nation and state. The definition of education, education has at least two functions. First progressive function. In this function, educational activities can provide knowledge and development, inculcate values and skills in anticipating the future so that the next generation of the nation has the ability and readiness to face challenges in the present and the future. The second function of conservative education is how to pass down and maintain the ideals and culture of a society to the next generation. If the two functions of education are related to the existence and nature of human life, in essence education is directed at the formation of the human personality. 


\section{Character Formation through Internalization of Religious Values in Elementary School Students}

Developing humans as individual beings social beings moral beings and religious beings (religious). So, it can be said that the main purpose of holding education is not to create intellectually intelligent students, but also to build the personality of students. According to Budiyanto (2010:7), education is to prepare and grow students or human individuals whose process takes place continuously from birth to death. The aspects that are prepared and grown include aspect of the body, mind, and spirit as a whole without neglecting one aspect and exaggerating other aspects. The preparation and growth is directed to become a human being who is efficient for himself and for society and can obtain a perfect life. Education applies to everyone and can be done by everyone, even the environment, and is carried out by special institutions or institutions in order to bring them to maturity.

Comprehensively that education is all activities or conscious efforts made by educators to student on all aspects of personality development, both physically and spiritually. Formally, informally, and none formally that run continuously to achieve happiness and high values (both human and divine values).

\section{Definition of Character}

Character etymologically comes from the Latin character, which among other things means character, traits, psychology, character, personality, and morals. Character is a person's nature that can be formed and changed even though it contains innate elements that each person is different. Character is a trait in humans that exists without being desired and attempted. Budi character is the values of human behavior that are measured according to their goodness and badness through religious norms, legal norms, etiquette and manners, cultural norms and community customs. Morals are rules that teach how one should relate to God as well as how one should relate to humans. In terminology, character is defined as human nature in general which depends on the factors of his own life. Character is a psychological, moral, or character trait that characterizes a person's group of people. Character are values related to God Almighty, oneself, fellow human beings, environment and nationality which are manifested in thoughts, attitudes, feelings, words, and actions based on religious norms, laws, karma, culture, and customs, then character is the character or character of a person which is a special personality, and which distinguishes him from others.

According to Albertus (2010:80), character is associated with temperament which gives him a definition that emphasizes psychosocial elements associated with education and environmental contexts. Character is also understood from a behavioral point of view which emphasizes the psycho elements possessed by individuals from birth. Character is considered the same as personality. Personality is considered as a characteristic or characteristic or style or characteristic of a person, which comes from formations received from the environment, for example, family influences in childhood and innate someone from birth. A person's character is formed because of the habits on does, the attitude taken in response to the situation, and the words spoken to others. This character eventually becomes something that sticks to a person and often the person concerned is not aware of his character. Other people are usually easier to judge a person character. A person habits are formed from actions that are repeated every day. These actions are initially conscious or intentional, but because so often the same actions are carried out, in the end often these habits become reflexes that are not realized by the person concerned. For example: gait, body movement when speaking in public or language style.

People take action because they want to do it. From persistent desire finally what is desired is done. The emergence of desire in someone is driven by a thought or something. There are many things that can trigger the mind whose information comes from the five senses. For example, seeing something makes people think, hearing something makes people think and so on.

\section{Definition of Character Education}

According to the National Education System Law, article 1 of 2003 states that one of the goals of national education is to develop the potential of students to have intelligence, personality, and noble character. So that education does not only from intelligent Indonesian people, but also has personality or character. Thus, a generation of nations is born that grows and develops with characters that breathe the noble values of the nation and religion. According to Albertus (2010: 100), character education is able to become the driving force of history towards the aspired golden Indonesia. In character education, humans are seen as able to overcome determination outside them with a value that is valuable and worth fighting for, he can overcome his limitations, thus, the values that are believed by individuals that are embodied in decisions and actions become the driving force.

From an Islamic perspective, character education can be defined as a conscious and planned effort to shape, direct and guide the morals of students in daily life in accordance with Islamic teachings sourced from the Koran, hadith, and ijtihad. Even Rasulullah SAW was sent to be the best example for humans (QS. Al-Ahzaab:31), because he has a great character (QS. AlQalam:4). According to Muslim Nurdin, et.al. (2001:205), character education in an Islamic perspective is moral education. Moral 


\section{Character Formation through Internalization of Religious Values in Elementary School Students}

comes from the word khalaqa with the root word khuluqan (Arabic) which means war, character, custom, or from the word khalqun (Arabic) which means event, creation, or creation. So, etymologically, morals, manners, customs, habits, or systems of behavior are made. Morals can be good or bad. Good morals are called good morals and bad morals are called madzmumah moral. However, in Indonesia the word morality always has a positive connotation. Good people are called moral people and people who do bad things are often called people who have no morality.

According to Zubaedi (2012:65), character education has a general meaning, namely the formation of character that is carried out by all people, both Muslims and other religious people. However, the difference is not a reason to be contested. Character education is based on the basic human character that comes from universal moral values (absolute) of religion, which is also known as the golden rule. Character education has a definite purpose, if it is based on these basic character values. According to psychologists, some of these basic character values include love for Allah SWT and his creation (nature and its contents), responsibility, honesty, respect and courtesy, compassion, caring and cooperation, self confidence, creativity, hard work and abstinence, surrender, justice and leadership, kindness and humility, tolerance, love of peace, and love of unity.

The implementation of character education in schools must be based on basic human character values. Furthermore, it is developed into more or higher values (which are not absolute, relative) according to the needs, conditions, and school environment. Character education in schools, all components must be involved. These components include the curriculum, learning and assessment process, handling or managing subjects, school management, implementing co curricular activities, empowering infrastructure, financing, and the work ethic of all school members or the environment. According to Sudrajat (2011:45), character education is an effort that is designed and implemented systematically to help students understand the values of human behavior related to God Almighty, oneself, fellow human beings, the environment and nationality which is manifested in thoughts, attitudes, feelings, words and action based on religious norms, laws, etiquette, culture and customs.

Character education is a planned process to shape, direct and guide the behavior of students in everyday life in accordance with the norms prevailing in society. These norms regulate the pattern of human attitudes and actions wherever they are. In these norms there is a value system. If it is interested in an Islamic context, the value system is Islamic teachings with the Al-Qur'an and Hadith as the source of its value and ljtihad as a method of Islamic thinking. The pattern of attitudes and actions resulting from the Islamic values system in question includes relationship with Allah SWT, fellow humans and with the natural surroundings.

\section{Character Education Goals}

The purpose comes from the root word to aim, the verb is towards which means to go in the direction and to lead and to make a purpose (target, direction). That is why the goald is defined as a direction, something to aim for and achieve. The purpose of character education is to inculcate values in students and to renew the order of living together that values individual freedom more. Its long term goal is to base itself on an individual's active contextual response to the natural social impulses it receives, which in turn sharpens the vision of life that will be achieved through an ongoing formation process. This long term goal is a dialectical approach that is closer to the ideal reality, through a process of continuous reflection and interaction between idealism, choice of means and direct results that can be evaluated objectively.

According to Nurchaili (2010:55), it is very important to plant character education as early as possible. Because with good character, we can do things that are proper, good and right so that we can take part in life success, harmony among others and be in the corridor of good behavior. On the other hand, if we violate it, we will experience uncomfortable things, from light ones, such as not being liked, not being respected by others, to serious ones such as breaking the law. Character education also aims to improve the quality of implementation and educational outcomes in schools that lead to the achievement of the formation of character and noble character of students in a complete, integrated and balanced manner in accordance with graduate competency standards. Through character education, it is hoped that students will be able to independently improve and use their knowledge, examine and internalize and personalize character values and noble character so that they are manifested in daily behavior.

According to Majid (2013:108), the main goal of education which has been neglected or may have failed to be achieved is the formation of character. This neglect or failure can be seen from various things. Children are not polite to their parents and older people, care less about others, dirty words that are far from ethics, disputes and brawls between students, promiscuity, smoking and drugs are common things that we often see and find anywhere. Therefore, to improve the morality and character of students, character education should be implemented. The internalization of character education will increasingly indirectly become a force to select and filter any challenges that come from outside, whether in the form of western culture, community values, and thoughts that pass before humans through print and electronic media. The war of thought, culture, economy, 


\section{Character Formation through Internalization of Religious Values in Elementary School Students}

morals, and values is happening so fiercely in today's era of open competition, so that tough and consistent individuals and communities are needed to live up to the sacred and noble values that they believe in.

These great values will become transformer figures to inspire and motivate people to preserve and fight for great values that are believed to be true, as well as dynamic and progressive in developing these values so that they are always relevant to contemporary challenges that require continuous adaptation, contextualization, and revitalization processes. Character education is very important because of its strategic position in pumping the human spirit in preserving and fighting for these great values. For this reason, character education is expected to be able to produce and display a generation that not only has intellectual intelligence, but also has emotional and spiritual intelligence and has a personal character who always tries to maintain his development by improving the quality of moral faith, relationships between fellow humans and realizing the motto of a happy life, the world and the hereafter.

\section{The Urgency of Character Education}

Character education is an urgent need considering that demoralization and degradation of knowledge have become increasing in acute affecting this nation at all levels of society. Character education is expected to be able to raise the awareness of this nation to build a solid national foundation. Through the Ministry of National Education, the government has launched the implementation of character education for all levels or education, from elementary to university. The emergence of the idea of character education programs in the world or education in Indonesia is understandable, because so far it is felt that the education process has not succeeded in building Indonesian people with character. Many say that education has failed to build character. Many high school graduates and scholars are good at answering exam questions and are intelligent, but mentally weak and timid, and their behavior is not commendable. This is what urges the birth of character education. Many research result prove that character can affect a person's success.

Among them, the result or research at Harvard University, United States in Asmani (2013:78), which states that it turns out that a person's success is not determined solely by knowledge and technical abilities (hard skills), but by the ability to manage oneself and others (soft skills). This research reveals that success is only determined about $20 \%$ by hard skills, and the rest $(80 \%)$ by soft skills. In fact, the most successful people in the world can succeed because they are supported by soft skills rather than hard skills. This implies that the quality of student character education is very important to improve.

\section{The Urgency of Character Education}

Character education is an urgent need considering that demoralization and degradation of knowledge have become increasing in acute affecting this nation at all levels of society. Character education is expected to be able to raise the awareness of this nation to build a solid national foundation. Through the Ministry of National Education, the government has launched the implementation of character education for all levels or education, from elementary to university. The emergence of the idea of character education programs in the world or education in Indonesia is understandable, because so far it is felt that the education process has not succeeded in building Indonesian people with character. Many say that education has failed to build character. Many high school graduates and scholars are good at answering exam questions and are intelligent, but mentally weak and timid, and their behavior is not commendable. This is what urges the birth of character education. Many research result prove that character can affect a person's success.

Among them, the result or research at Harvard University, United States in Asmani (2013:78), which states that it turns out that a person's success is not determined solely by knowledge and technical abilities (hard skills), but by the ability to manage oneself and others (soft skills). This research reveals that success is only determined about $20 \%$ by hard skills, and the rest $(80 \%)$ by soft skills. In fact, the most successful people in the world can succeed because they are supported by soft skills rather than hard skills. This implies that the quality of student character education is very important to improve.

\section{The Urgency of Character Education}

Character education is an urgent need considering that demoralization and degradation of knowledge have become increasing in acute affecting this nation at all levels of society. Character education is expected to be able to raise the awareness of this nation to build a solid national foundation. Through the Ministry of National Education, the government has launched the implementation of character education for all levels or education, from elementary to university. The emergence of the idea of character education programs in the world or education in Indonesia is understandable, because so far it is felt that the education process has not succeeded in building Indonesian people with character. Many say that education has failed to build character. Many high school graduates and scholars are good at answering exam questions and are intelligent, but mentally weak and timid, and their behavior is not commendable. This is what urges the birth of character education. Many research result prove that character can affect a person's success. 


\section{Character Formation through Internalization of Religious Values in Elementary School Students}

Among them, the result or research at Harvard University, United States in Asmani (2013:78), which states that it turns out that a person's success is not determined solely by knowledge and technical abilities (hard skills), but by the ability to manage oneself and others (soft skills). This research reveals that success is only determined about $20 \%$ by hard skills, and the rest ( $80 \%$ ) by soft skills. In fact, the most successful people in the world can succeed because they are supported by soft skills rather than hard skills. This implies that the quality of student character education is very important to improve.

Therefore, educational institutions must determine the standard demands on the character that will be offered to students as part of their institutional performance; $d$. priority praxis, another very important element for character educational is evidence of the implementation of the priority values of character education. In connection with the demands of educational institutions on the priority values that become the vision of the their educational performance, educational institutions must be able to verify the extent to which the schools vision has been realized within the scope of scholastic education through various elements that exist within the educational institution itself; $d$. reflection, the character that educational institutions want to shape through various programs and policies always needs to be evaluated and reflected on continuously and critically. Because, as Socrates said, "A life that is not reflected is a life that is not worth living". Without an effort to look back at the extent to which this reflected and evaluated, there will never be progress. Reflection is this conscious ability, humans are able to cope with themselves and improve their quality of life better. So, after the actions and praxis of character education have taken place, it is necessary to conduct a kind of deepening and reflection to see the extent to which educational institutions have succeeded or failed implementing character education. Humans are able to cope with themselves and improve their quality of life better. So, after the action and praxis of character education have taken place, it is necessary to conduct a kind of deepening and reflection to see the extent to which educational institutions have succeeded or failed in implementing character education. Humans are able to cope with themselves and improve their quality of life better. So, after the actions and praxis of character education have taken place, it is necessary to conduct a kind of deepening and reflection to see the extent to which educational institutions have succeeded or failed in implementing character education.

The character education methodology is an important note for all parties, especially teacher who interact directly with students. Of course, these five things are not the only ones, so each of them is challenged to present alternative thoughts and ideas to enrich the character education methodology that this nation desperately needs in the future.

\section{Strategy of Internalizing Religious Values in Character Building}

The character education methodology is an important note for all parties, especially teachers who interact directly with students. Of course, these five things are not the only ones, so each of them is challenged to present alternative thoughts and ideas to enrich the character education methodology that this nation desperately needs in the future. Likewise, the internalization of religious character also has systematic method. There are many methods that can be used by teachers, principles, and schools in internalizing the religious character of students. It is hoped that with a strategy that is suitable for the child's religious character, it can be achieved to the maximum. One thing that teachers need to pay attention to in presenting religion to children is that it must be in accordance with the growth of the child's soul, in a more concrete way.

\section{Integration through School Management}

The character education methodology is an important note for all parties, especially teachers who interact directly with students. Of course, these five things are not the only ones, so each of them is challenged to present alternative thoughts and ideas to enrich the character education methodology that his nation desperately needs in the future. Likewise, the internalization of religious character also has a systematic method. There are many methods that can be used by teachers, principals, and schools in internalizing the religious character of students. Then from these methods various strategies for internalizing religious character can be developed. It is hoped that with a strategy that is suitable for the child's religious character, it can be achieved to the maximum. One thing that teachers need to pay attention to in presenting religion to children is that it must be in accordance with the growth of the child's soul, in a more concrete way.

\section{Integration through School Management}

Management implies the use of resources to achieve goals. Resources are elements in management, namely humans (man), materials (materials), machines or equipment (machine), methods or ways of working (methods), money capital (money), and information (information). Resources are limited so that the task of management must manage limited resources efficiently and effectively so that goals are achieved. The management process is a continuous process, starting from planning and making decisions (planning), organizing the resources oqned (organizing), applying leadership to mobilize resources (actuating), to implementing control (controlling). This process is often referred to as the POAC (Planning-Organizing-Actuating-Controlling) concept, which originated in the west. This is different from the Japanese approach, known as the PDCA (Plan-Do-Check-Action) 


\section{Character Formation through Internalization of Religious Values in Elementary School Students}

approach. The contextual on the world of educations, which is meant by education Management is a process of planning, implementing, and evaluating education in a effort to produce graduates who are in accordance with the vision, mission, and goals of education itself.

Table 1. Indicator of School and Class Success in Instilling Religious Character

\begin{tabular}{|l|l|}
\hline School Indicator & Class Indicator \\
\hline $\begin{array}{ll}\text { a. Celebrating religious holidays } \\
\text { b. Has facilities that can be used for worship } \\
\text { c. Provide opportunities for all students to } \\
\quad \text { carry out worship }\end{array}$ & a. Pray before and after the lesson \\
& to carry out worship \\
\hline
\end{tabular}

According to the Ministry of National Education, the success of failure of schools and classes in instilling values is measured by the indicators as shown in table 1. If a school and class has met the above indicators, it can be stated that the school and class have succeeded in instilling religious character values, to the students. Character education in schools is also closely related to school management or management. The management in question is how character education is planned, implemented, and controlled in educational activities in school adequately. The management includes, among others, the values that need to be instilled, curriculum content, learning, assessment, educators, and education staff, as well as other related components, in character education into the existing school curriculum, syllabus, and learning program plans (RPP). As for the implementation of character education through self development and habituation, what Kurniawan mentioned is written in table 2, regarding the implementation of character education in the following school curriculum. :

Table 2. Implementation of Character Education in School Curriculum

\begin{tabular}{|l|l|l|}
\hline No. & $\begin{array}{l}\text { Implementation of Character } \\
\text { Education }\end{array}$ & Form of Activity Implementation \\
\hline 1 & Integration in existing subjects. & $\begin{array}{l}\text { Develop syllabus and lesson plans on existing } \\
\text { competencies in accordance with the values that } \\
\text { will be applied. }\end{array}$ \\
\hline 3 & Self development activities & $\begin{array}{l}\text { Determined by the school/region. Competencies } \\
\text { are developed by the school /region. }\end{array}$ \\
& a. Cultivation and habituation, in the form of, \\
& & $\begin{array}{l}\text { conditioning, routine activities, spontaneous } \\
\text { activities, exemplary, and programmed } \\
\text { activities. } \\
\text { b. Extra curriculum activities, such as scouts, } \\
\text { PMR, UKS, KIR, honestly canteen, sports, arts } \\
\text { and so on. } \\
\text { Counseling guidance is the provision of } \\
\text { services for children who have problems. }\end{array}$ \\
\hline
\end{tabular}

Habituation is an activity that is carried out repeatedly to achieve a change in behavior. Of course, this behavior change is a good behavior. The change in good behavior then becomes the goal to be achieved in habituation activities. There are three forms of habituation activities that can be carried out, as follows:

\section{Regular Habit}

Routine activities are activities carried out by students continuously and have been carried out every day. Routine activities carried out every day can be used as a habit in internalizing religious character in students. Routine habituation is a habituation activity that is carried out on a programmed or scheduled basis. It can be carried out in one daily, one weekly, one mount one semester, even one year activity. In the opinion of Kurniawan (2013:129), revealed that religious activities can be taught to student in schools which can later be used as habits, namely; a. pray or give thanks. Prayer is an expression of gratitude to God. Expression of gratitude can also be realized by establishing brotherly relations among friend without discriminating against ethnicity, race, and religion; b. organizing activities at the mosque. Activities that can be carried out are for example zuhur prayer in congregation every day, participating in Qurban recitation activities together, and congregational Friday prayers; c. Organize religious holidays. 


\section{Character Formation through Internalization of Religious Values in Elementary School Students}

For those who are Muslim, for example, holding religious activities such as recitations at the moment of Eid al-Adha, Eid al-Fitr, and Isra Mi'raj as a means of increasing the faith and piety of students. This routine activity is important for teachers to do to shape the habituation of student's attitudes and behavior to suit their religious character. Because with the habituation of religious character can be internalized in the soul of the child. So when the child does not behave in accordance with the character, then he will feel guilty and uncomfortable.

\section{Spontaneous Habituation}

Spontaneous habituation is a habituation activity that is not programmed. In other words, spontaneous habituation is a habituation activity that is carried out incidentally in certain situations or when students display certain behaviors (either good behavior or bad behavior). The forms of spontaneous habituation include the following: a. giving gifts in the form of material (goods, materials) and non-material (praise, smiles, congratulations, etc.) for good behavior displayed by students in a situation. For example, teachers are used to giving praise to students who come to school early ; b. Giving punishment or warning and advice to students who do bad behavior. For example, teachers are accustomed to giving punishment to students who violate school rules to provide a deterrent effect so that students do not violate them again. The teacher's habit of giving rewards and punishments for various behaviors displayed by students can be used as a medium to teach which actions should be taken and which actions should not be done in character education practice.

\section{Habituation Exemplary}

Exemplary habituation is a habituation activity carried out by teachers to always provide real examples of good to their students. The example in question is all the behaviors and attitudes carried out by school supervisors, principals, and school employees in providing examples of good actions, so that they can become good models for students. The teacher is a figure who is admired and imitated for students and the community. This means that teachers must be able to be role models for their students. In fact, there are those who think that the success of teachers in shaping the character of their students will be greatly influenced by their ability to get used to providing examples for their students.

Teachers exemplary is very important for the effectiveness of character education. Without example, character education loses its most essential spirit, only slogans, camouflage, mirages, and other negative words. Exemplary is easy to say, but hard to do. Because, exemplary is born through a long educational process, starting from material enrichment, reflection, appreciation, experience, resilience, to consistency in actualization. Education is experiencing a crisis of exemplary. This is what causes the degradation of knowledge and moral decadence to become acute in this country. Many teachers whose attitudes and behavior cannot be example for student. They have lost a mentor they can admire and emulate. Finally, they are wild in expressing freedom. There was a moral crisis. Their idols were stars who liked to flaunt their beauty beyond limits. Furthermore, nowadays, many students have become men's ideal women because of the influences of cultural globalization which is perverted and misleading.

Teachers and parents also need to have assertive skills and listening skills. Assertive skills are the skills to express opinions openly, in ways that do hurt the feelings of others. The value exemplary method has implementation strategies, the value exemplary strategy includes: sharing feelings, sharing experiences, sharing skills, resources persons, and avoiding hypocrisy.

\section{Role of Family Environment}

The family environment is the smallest unit of society consisting of the head of the family and several people who gather and live in on place under one roof in a state of interdependence. The family environment is the main pillar to shape the good and bad of the human person in order to develop well in ethics, morals, and morals. The role of the family can shape the pattern of attitudes and personality of children can also determine the educational process that children get, not only at school but all factors can be used as sources of education. The family environment can also play a role as a source of children's knowledge, it can also affect the success of student achievement. The family function is an educational function where the family is the best vehicle in the process of socialization and education for children. The family becomes a vehicle for educating, nurturing, and socializing something to children, developing the abilities of all its members so that they carry out their functions in the community well and prosper.

Family is an important aspect to instill character in children so that children so that children have good character, especially parents, are the main educators who play an important role in shaping the character of children who always strive to educate their children, both in the cognitive field and also in educating values and morals. The family is the first and foremost place for children's growth and development. The basis of character education should be applied from childhood or what psychologist call the golden age, because this age has been proven to greatly determine a child's ability to develop his potential. 


\section{Character Formation through Internalization of Religious Values in Elementary School Students}

About $50 \%$ of the variability of adult intelligence occurs when the child is 4 year. The next $30 \%$ increase occurs at the age of 8 years, and the remaining $20 \%$ in the middle or late second decade. From here, character education should start from within the family which is the first environment for the growth of children's character.

Teachers and parents also need to have assertive skills and listening skills. Assertive skills are the skills to express opinions openly, in ways that do hurt the feelings of others. The value exemplary method has implementation strategies, the value exemplary strategy includes: sharing feelings, sharing experiences, sharing skills, resources persons, and avoiding hypocrisy.

\section{Role of Family Environment}

The family environment is the smallest unit of society consisting of the head of the family and several people who gather and live in on place under one roof in a state of interdependence. The family environment is the main pillar to shape the good and bad of the human person in order to develop well in ethics, morals, and morals. The role of the family can shape the pattern of attitudes and personality of children can also determine the educational process that children get, not only at school but all factors can be used as sources of education. The family environment can also play a role as a source of children's knowledge, it can also affect the success of student achievement. The family function is an educational function where the family is the best vehicle in the process of socialization and education for children. The family becomes a vehicle for educating, nurturing, and socializing something to children, developing the abilities of all its members so that they carry out their functions in the community well and prosper.

Family is an important aspect to instill character in children so that children have good character. Families, especially parents, are the main educators who play an important role in shaping the character of children who always strive to educate their children, both in the cognitive field and also in educating values and morals. Character is also included in the material that must be explained to students. Character education in the school environment should bring students to cognitive value recognition, affective value appreciation, and finally to real value practice. Therefore, character education that has existed in the school environment needs to be immediately reviewed and alternative solutions are sought, and need to be developed more operationally so that it is easy to implement. Character education in the school environment can be integrated into learning in each subject. Learning materials related to norms or values in each subject need to be developed, made explicit, and linked to the context of everyday life. Thus, learning character values is not only at the cognitive level, but also touches on internalization and real experiences in the daily lives of students in society.

\section{The Role of the Community Environment}

The community environment is an important part, because after children are educated in the family and school environment, they will live in the community. As a non formal education environment, the community should also play a role in the implementation of the character education process. Every individual as a member of the community must be responsible for creating a comfortable and supportive atmosphere. In children's education, parents should choose an environment that supports children's education and avoids a bad community environment. Because, a child or student is in a bad society, the development of the child's character or personality can become less good. Parents must choose a healthy and suitable community environment as a place to live for parents and their children. Likewise, schools as a formal education environment, also need to choose a good community environment so that they can support the educational process.

According to Salim (2012:271), the importance of the role of the community as a center for character means that every individual as a member of society must create a comfortable atmosphere for the continuity of the educational process that occurs in it. In Indonesia, the concept of community based education is known as a effort to empower the community in providing education. Although this concept is more often associated with schools as formal education, the existence of this concept also shows that public awareness is needed, and its existence is very influential, towards the implementation of education in schools. In the implementation of character education, an integrated character education center is needed, namely the family, school and community environment.

\section{RESEARCH FINDING}

Description of Research Site, SD Lab School FIP-UMJ South Tangerang, Indonesia, is a pilot project school for the Ministry of Education and Culture's character education strengthening program. So that this school has implemented character that has a positive impact on the students of SD Lab School FIP-UMJ. Through daily habits carried out through superior programs SD Lab School FIP-UMJ is committed to educating and fostering students to become individuals of character so that all learning activities, both intra curriculum, co-curricular and extra-curriculum are directed at building the character of students who are religious, nationalist, independent, mutual cooperation, and integrity. The school situation is very supportive for the 


\section{Character Formation through Internalization of Religious Values in Elementary School Students}

internalization of religious values is character building in students. This is supported by the existence of various activity program held by teachers and schools that are thick with religious elements and are supported by the availability of school facilities used to implement the program. The following are the names of the informants from interviews conducted by researches, namely as follows:

Graph 1. Characteristics of Respondents by Gender

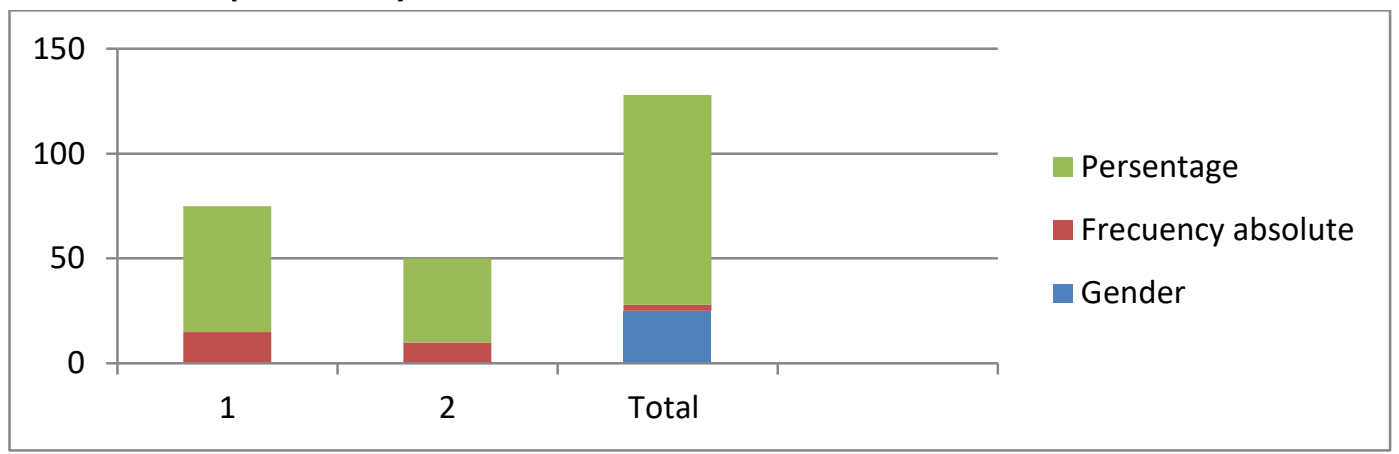

The data above shows the characteristics of the respondent's gender, which consists of 1 male, namely Mr. DR as the head of the school, and 2 women namely Ms. EP as homeroom teachers for class 4.1 and Ms. RF as students vice principal. The percentage obtained is $33.3 \%$ for male respondents and $66.7 \%$ for female respondents. The following are the characteristics of respondents based on age as follows:

\section{Graph 2. Characteristics of Respondents by Age Category}

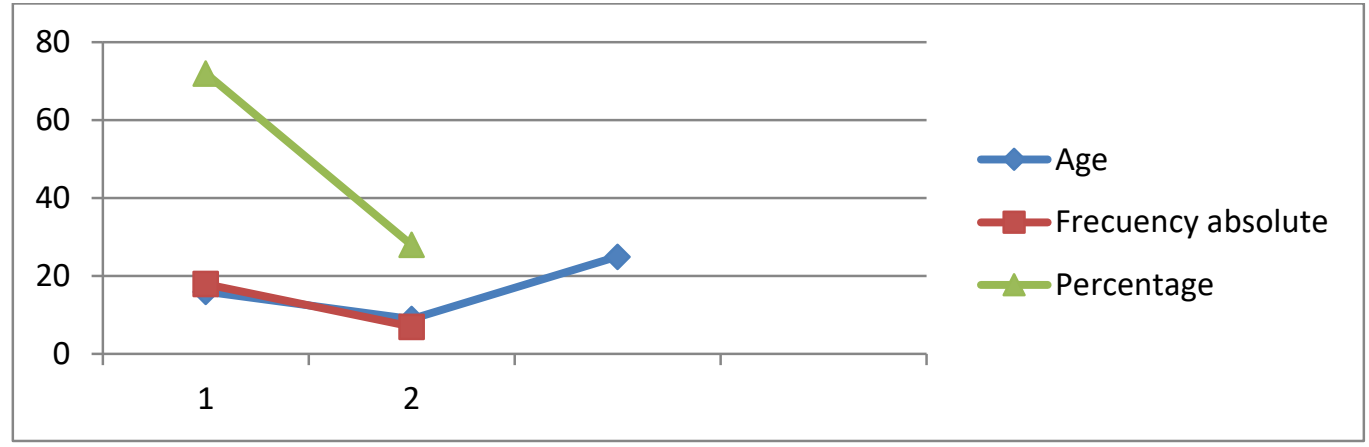

The data above shows the characteristics of respondents based on the age category of children in grade 4 . This category is divided into 2, namely the 9 year age category, and the 10 year age category. In the 9 year age category there are 4 children, and the 10 year age category there are 3 children. The percentage of numbers in the 9 year age category showed $57.1 \%$ and $42.9 \%$ for the 10 years age category. Respondents data are presented based on the type of work, as follows :

Graph 3. Characteristics of Respondent by Gender

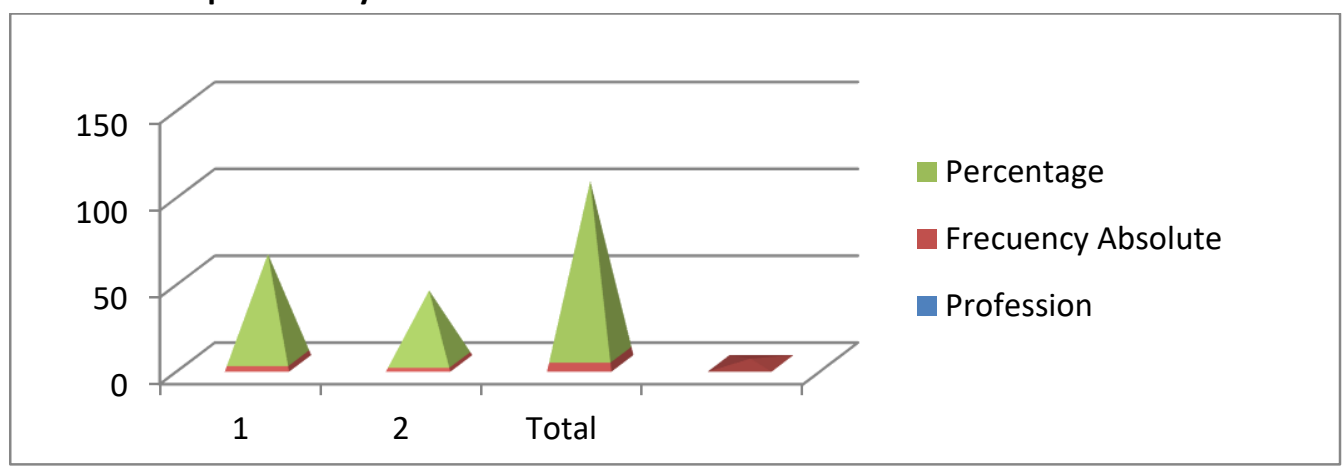

The result of the data collection above show the number of characteristics of the respondent based on the type of work of the guardians of grade 4.1. The table above shows that there are 2 types of work for the guardians of grade 4.1 students, namely housewives and civil servants (PNS). With the percentage of data for each type of work, $60.0 \%$ is the percentage for the type work for housewives and $40.0 \%$ for the type of work for civil servants. 


\section{Character Formation through Internalization of Religious Values in Elementary School Students}

\section{DESCRIPTION OF RESEARCH RESULTS}

The value of Internalized Religious Character, based on the results of the study, it was found that several activity program ini SD Lab. School FIP-UMJ, South Tangerang, Indonesia, including the flagship program, namely character based education where SD Lab. School FIP-UMJ South Tangerang, Indonesia, is committed to educating and fostering students to become individuals with character, so that all learning activities, both intra curricular, co curriculum, and extra curriculum are directed at the formation of student's religious, nationalist, independent, mutual cooperation, and integrity character. The habituation program is a routine activity carried out outside the Teaching and Learning Activities (KBM) which is carried out every day.

Broadly speaking, the habituation program at SD. Lab School FIP-UMJ, South Tangerang, Indonesia, is divided into three, namely, morning habituation which includes the movement to welcome students, dhuha prayer in congregation, tadarusan, morning journal, student appointments, memorizing murojaah, and controlling worship books. Then there is the afternoon habit which includes washing hands before eating, praying before and after eating, praying in and out of the bathroom, praying dzuhur in congregation, and closing prayer. Religious character values that are internalized in SD Lab School FIP-UMJ include tolerance, anti bullying, discipline, love to pray, always grateful, greeting, responsibility, and religious values are also applied by loving and protecting the environment.

This is based on the results of an interview with Mr. DR as the principal of the SD Lab School FIP-UMJ, as follows: there are so many religious values, the sub values include tolerance (respect for differences in religion, ethnicity, and race) including tolerance as well as respecting one's physical differences because we (Lab School) are inclusive schools. For example, there are students with disabilities who cannot walk, mean needing help, how the student appreciates, helps, and so on. Then again the values of anti bullying or anti-violence, so we (Lab. School) than God this school can be said to be zero bullying, there is no bullying, especially bullying which is usually done between upperclassmen and under classmen. No one in $6^{\text {th }}$ grade goes into the lower class, it doesn't exist. Always pray when you are about to start or after something, always be grateful for what Allah has given you. Then also the religious character that is applied by loving and protecting the environment is one of the religious characters too, so how can children be taught to water the plants every morning".

Internalization of religious character through self development programs in SD Lab. School FIP-UMJ is carried out by extracurricular activities. There are lots of extracurricular activities at SD Lab. School FIP-UMJ. Based on the results of observations made by researches self-development activities for elementary school students. Lab. School FIP-UMJ through extracurricular is held every Wednesday. So in a week of teaching and learning activities at school, there is that is used only for extracurricular activities, which is always carried out every Wednesday from morning to evening for the self development of elementary school students Lab School FIP-UMJ.

\section{School Routine Activities}

Based on the results of the interview with Ms. EP, the implementation of the process of internalizing religious values in the formation of student character at SD Lab School FIP-UMJ is programmed in the habituation program ini routine school which is carried out outside of Teaching and Learing Activities (KBM) and takes place every year. There is habituation in the morning which includes morning journals, dhuha prayer in congregation, reading Pledged, and reading Iqro/Al-Qur'an. The implementation of routine student activities in the morning habituation was the congregational dhuha prayer which was carried out in their respective classes, then after the dhuha prayer there was a tadarus habituation (reading Iqro/Al-Qur'an), after the tadarus there was a morning journal where the students lined up in front of the students. Class to read the student's promise (Pledge) followed by singing the national anthem and then closed with memorizing murojaah.

\section{Spontaneous Activities}

Spontaneous activities are habituation activities that are not programmed. Spontaneous habituation is habituation activities that are carried out incidentally in certain situation or when students display certain behavior. Based on the results of an interview with Ms. RF as student representative at SD Lab. School FIP-UMJ, she said that: "Besides praying, the children are also accustomed to salaam to the teacher, continue to say greetings and maintain speech. Usually if there are children who speak words that are not good, because it has been accustomed from the beginning of the establishment of the Lab School from Mrs. Echi at that time, it is not permissible to use the word loe-gua as well as getting used to when we see her friends make mistakes or something is inappropriate, we usually do I'm sorry, I'm used to it from the very beginning of Lab School. The following are the results of student attitudes that emerged through spontaneous activities which are presented in the table as follows: 


\section{Character Formation through Internalization of Religious Values in Elementary School Students}

Table 3: Student Efforts and Attitudes through Spontaneous Activities

\begin{tabular}{|l|l|l|l|}
\hline No. & Effort & Developed Value & Student Attitude \\
\hline 1 & $\begin{array}{l}\text { Reprimand students who did not } \\
\text { immediately carry out worship. }\end{array}$ & Worship & $\begin{array}{l}\text { All students want to immediately } \\
\text { pray, when the teacher is reminded. }\end{array}$ \\
\hline 2 & $\begin{array}{l}\text { Give praise to students } \\
3\end{array}$ & $\begin{array}{l}\text { Give advice to students who } \\
\text { make mistakes. }\end{array}$ & $\begin{array}{l}\text { Worship } \\
\text { they do something wrong, because } \\
\text { they are afraid of Allah. }\end{array}$ \\
\hline 4 & $\begin{array}{l}\text { The teacher participates in } \\
\text { prayer activities before and after } \\
\text { the lesson }\end{array}$ & Worship & $\begin{array}{l}\text { Students are happy when they get } \\
\text { praise from the teacher. }\end{array}$ \\
\hline 5 & $\begin{array}{l}\text { The teacher follows or } \\
\text { participates in observing the } \\
\text { activities of the dhuha and } \\
\text { dzuhur prayers in congregation }\end{array}$ & Worship & $\begin{array}{l}\text { Students want to imitate the teacher } \\
\text { when praying with a solemn attitude. } \\
\text { Students want to imitate the teacher } \\
\text { by following reading and tadarus. }\end{array}$ \\
\hline
\end{tabular}

\section{Giving Exemplary}

Giving exemplary is a habituation activity carried out by teachers to always provide examples of good deeds to their students in real terms. This means that teachers must be able to be role models for their students. So the method used in the Lab School do is how children have good habits, of course the first is an example, especially the example of a teacher, how a teacher respects his students, how a teacher loves cleanliness is an example of an example. So it is only exemplary that can shape the character of students, religious character itself when the dhuha time the teacher joins the dhuha prayer, when reciting the Koran and becomes a student mentor, when the midday prayer, the teacher joins the midday prayer, it is an example".

Extracurricular activities are educational activities outside of subjects and counseling services to assist the development of students according to their needs, potential, talents, and requests through activities that are specifically organized by capable and authorized educators and/or educational staff in schools. Integrated character education in learning is the introduction of values, gaining awareness of the importance of values, and internalizing values into student's daily behavior through the learning process, both in the classroom and outside the classroom in all subject. These value are included in the syllabus and lesson plans. Learning materials related to norms or values in each subject need to be developed, made explicit, and linked to the context of student daily lives. Thus the learning of character values is not only at the cognitive level, but comprehensively at the internalization, real experience data in the daily lives of students in society.

Internalization of religious character through internalization in learning in SD Lab. School FIP-UMJ just goes on every ongoing learning process, this was also stated by Ms. EP as a grade 4teacher in her interview, as follows: "It just works, so we (Lab School) is already used to it and it's a habit, so friends (students) do it without being asked and it runs as usual. Religious Characters Listed in the Syllabus. Based on the results of the interview with Ms. EP as a grade 4.1 teacher, the internalization of religious values in character building was included by the teacher in the learning syllabus. SD Lab. School application of religious values. Read a prayer before starting the lesson, then give thanks for what God has given, all of which is stated and written in the lesson plans and syllabus", based on the results of the research's documentation the syllabus that the teacher uses comes from the government so that the teacher just need to develop the syllabus into the learning process.

\section{Religious Characters Written in RPP}

Based on the results of the interview with the EP teacher as homeroom teacher for class 4.1 as shown in the description of the research results above, the teacher has included religious values in the formation of students character in the lesson plans, in the formation of characters already listed in the lesson plan at point D the expected student character. In the RPP the expected student characters are listed not only religious characters but also other characters such as nationalist, independent, mutual cooperation and integrity and many others.

Initial Activities, Core Activities, and Closing Activities, Based on the result of an interview with the EP teacher as homeroom teacher for grade 4.1 regarding how EP had internalized religious values into learning activities at school, Ms EP stated : "It just works, so we (Lab School) are already used to it and it is a The habit of being friends (students) does it without being asked and has run as usual. Already accustomed, "So based on the results of the interview with Ms. EP that during the 


\section{Character Formation through Internalization of Religious Values in Elementary School Students}

learning process in the classroom by internalizing religious values in the formation of students it just goes because the students are already used to it, this is a habit so students do it without being asked and it runs as usual.

\section{Interpretation of Research Results}

From and Islamic perspective, character education can be defined as a conscious and planned effort to shape, direct, and guide the morals of students in daily life in accordance with Islamic teachings originating from the Koran, hadith, and ljtihad. In the perspective of Islamic education, character values are widely studied in moral education. Even the Prophet Muhammad was sent to be the best example for humans (Surah Al-Ahzaab:21), because he has a great character (Surah Al-Qalam:4). The greatness of the personality of the Prophet Muhammad has been integrated into daily behavior and activities which are reflected in four characteristics: sidiq (true), amanah (trustworthy), tabligh (delivering the truth), and fathonah (wise). These four traitsare the big umbrella in character education, meaning that the values of character and national culture are the essence education, which is the embodiment of the four traits and characters of the Prophet Muhammad as described above.

Religious character education is an important foundation or foundation instilled in children from an early age. Religious character is the foundation in building a child's character, if the religious character is good, the other characters will also be good. Seeing the importance of character education, especially religious values in forming the character of students, it must be carried out and applied to students as early as possible so that it becomes a solid foundation for students so that in the future they are not easily carried away by the negative impacts of globalization and the negative impact of socializing trends.

\section{CONCLUSION}

Based on the results of the study, it can be concluded that the internalization of religious values in the formation of the character of elementary school students. Lab School FIP-UMJ South Tangerang, Indonesia as follows:

1. Strategies for internalizing religious values in character building of elementary school students SD Lab School FIP-UMJ South Jakarta, Indonesia, has been carried out and implemented well through the implementation of activities and habituation in SD Lab School FIP-UMJ. The internalization efforts made by the teacher, the attitudes of students that are formed, and the behavior of students that arise. The example of teachers that are formed, and the behavior of students that arise. The example of teachers participating in religious activities such as dhuha prayer in congregation, dzuhur prayer in congregation, praying before and after lessons and students tadarus activities that are formed are imitating the behavior that teachers do in participating in religious activities. The behavior that emerges is that students participate in praying with a good attitude.

2. Internalization of religious values in character building of students at SD Lab. School FIP-UMJ South Tangerang, Indonesia through learning activities in schools contained in the syllabus and lesson plans, school management as an educational system in character education which will then be managed through areas of planning, implementation, and control. And through extracurricular activities that exist in schools to help develop students according to their needs, potential, talents and interests through activities that are specifically organized by educators and/or educational staff who are capable and authorized at the school.

3. The role of extracurricular in the process of internalizing religious values in the formation of student characters has a fairly important role in the process of forming student character. Because, extra curriculum that are professionally designed can be in children, forming winning characters in children, and the greatest place of actualization that children are waiting for all the time.

\section{SUGGESTION}

Based on the conclusions, the suggestions that can be submitted by researchers are as follows:

1. Applications that are carried out must be more effective so that good habits emerge. Through habituation activities that are applied effectively, it can help the formation of children's character.

2. The learning in the syllabus and lesson plans should be designed effectively and appropriately so that the formation of children's character through learning activities can run optimally and well.

3. Extracurricular activities in schools should not only be mediocre in design, unattractive, monotonous, become a burd en for children, have no recreational and restorative value, and cause headaches and burdens for children. This must be avoided and becomes a challenge for school principals in empowering this extracurricular maximally, effectively, and productively for the development of children's character. 


\section{Character Formation through Internalization of Religious Values in Elementary School Students}

\section{REFERENCES}

1) Albertus. Doni Koesoema. (2010). Pendidikan Karakter; Strategi Mendidik Anak di Zaman Global. Penerbit: PT. Grasindo. Jakarta. Indonesia.

2) Asmani. Jamal Ma'mur. (2011). Buku Panduan Internalisasi Pendidikan Karakter di Sekolah. Penerbit: Diva Press. Yogyakarta. Indonesia.

3) Budiyanto Mangun. (2010). Menumbuhkan Sikap Religius Anak. Penerbit: PT. Gramedia Pustaka Utama. Jakarta. Indonesia.

4) Daradjat. Zakiyah. (2005). Ilmu Pendidikan Islam. Penerbit: Bumi Aksara. Jakarta. Indonesia.

5) Hariyanto. Muchlas Samani. (2013). Pendidikan Karakter. Penerbit: PT. Remaja Rosdakarya. Bandung. Indonesia.

6) Kamus Besar Bahasa Indonesia. (2002). Pengertian Nilai Religius. Jakarta: Kementerian Pendidikan Nasional. Republik

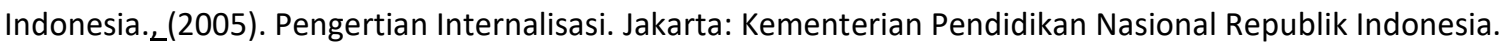

7) Kemendiknas. (2010). Pengembangan Pendidikan Budaya dan Karakter Bangsa Pedoman Sekolah. Kementrian Pendidikan Nasional Badan Penelitian dan Pengembangan Pusat Kurikulum dan Perbukuan. Jakarta. Indonesia.

8) Kurniawan. Syamsul. (2013). Pendidikan Karakter. Penerbit: Ar-Ruzz Media. Yogyakarta. Indonesia.

9) Mastuhu. M. (2007). Sistem Pendidikan Nasional Visioner. Penerbit: Lentera Hati. Tangerang. Indonesia.

10) Muhaimin. Akhmad. (2011). Urgensi Pendidikan Karakter Di Indonesia. Penerbit: AR-RUZZ MEDIA. Yogyakarta. Indonesia.

11) Mukhtar. (2013). Metode Praktis Penulisan Deskriptif Kualitatif. Penerbit: Referensi GP. Press Group. Jakarta. Indonesia.

12) Muslich. Manur. (2011). Pendidikan Karakter; Menjawab Tantangan Krisis Multidimensional. Penerbit: Bumi Aksara. Jakarta. Indonesia.

13) Mustari. Mohamad. (2014). Nilai Karakter Refleksi untuk Pendidikan. Penerbit: PT. Raja Grafindo Persada. Jakarta. Indonesia.

14) Nurchaili. (2010). Membangun Karakter Siswa Melalui Keteladanan Guru. Jurnal Pendidikan dan Kebudayaan Volume 16 Edisi khusus III, Balitbang Kementerian Pendidikan Nasional Republik Indonesia.

15) Nurdin. Muslim, dkk. (2001). Moral dan Kognisi Islam: Buku Teks Agama Islam untuk Perguruan Tinggi Umum. Penerbit: PT. Alfabeta. Bandung. Indonesia.

16) Pidarta. Made. (2004). Manajemen Pendidikan Indonesia. Penerbit: Rineka Cipta. Jakarta. Indonesia.

17) Salim. (2012). Peran Masyarakat Sebagai Pusat Pendidikan Karakter. Penerbit: Gema Insani. Jakarta. Indonesia.

18) Sugiyono. (2010). Metode Penelitian Kuantitatif, Kualitatif, dan R\&D. Penerbit: Alfabeta CV. Bandung. Indonesia.

19) Judiani Sri. (2010). Implementasi Pendidikan Karakter di Sekolah Dasar Melalui Penguatan Pelaksanaan Kurikulum, Jurnal Pendidikan dan Kebudayaan Volume 16 Edisi Khusus III. Oktober. Balitbang Kementerian Pendidikan Nasional. Republik Indonesia.

20) Wibowo. Agus. (2012). Pendidikan Karakter: Strategi Membangun Karakter Bangsa Berperadaban. Penerbit: Pustaka Pelajar. Yogyakarta. Indonesia.

21) Wiyani. Novan. (2013). Pendidikan Moral \& Budi Pekerti dalam Prespektif Perubahan. Penerbit: PT. Bumi Aksara. Jakarta. Indonesia.

22) Zubaedi. (2012). Desain Pendidikan Karakter: Konsepsi dan Aplikasinya dalam Lembaga Pendidikan. Penerbit: PT. Kencana. Jakarta. Indonesia.

23) Zuchdi. Darmiyati. (2015). Pendidikan Karakter. Penerbit: UNY Press. Yogyakarta. Indonesia.

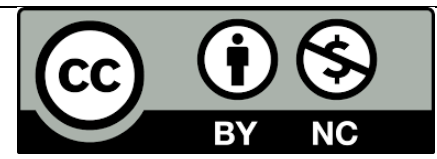

There is an Open Access article, distributed under the term of the Creative Commons Attribution - Non Commercial 4.0 International (CC BY-NC 4.0)

(https://creativecommons.org/licenses/by-nc/4.0/), which permits remixing, adapting and building upon the work for non-commercial use, provided the original work is properly cited. 